\title{
Treatment with Theresienöl - a new option in the management of vulvar leukoplakia
}

\author{
Angel Yordanov ${ }^{1}$, Strahil Strashilov ${ }^{2}$, Polina Vasileva ${ }^{3}$ \\ 'Department of Gynaecological Oncology, Medical University Pleven, Pleven, Bulgaria \\ ${ }^{2}$ Department of Plastic and Reconstructive Surgery, Medical University Pleven, Pleven, Bulgaria \\ ${ }^{3}$ Department of Obstetrics and Gynaecology, Medical University Pleven, Pleven, Bulgaria
}

\begin{abstract}
Introduction: The term vulvar leukoplakia encompasses a variety of non-inflammatory diseases that lead to skin discoloration of the external genitalia and white colouration. Most commonly, these are vulvar lichen sclerosus (VLS) and squamous cell hyperplasia of the vulva (SCHV). They have similar aetiology, clinical presentation, and treatment but different anatomical pathology.

Aim of the study: The study aims to determine the effect of Theresienöl herbal oil treatment in patients with clinically proven diagnosis of VLS and SCHV.

Material and methods: This prospective study includes 17 patients with a diagnosis of VLS and SCHV, who underwent a 3-month treatment course with Theresienöl herbal oil. All patients were followed up for 1 year after therapy initiation, and the effect of treatment was reported using a visual analogue scale (VAS) for genital itching.

Results: The median age of patients enrolled was 60.6 years (range 42-74); 2 patients dropped out due to failure to attend follow-up visits. The mean score of the VAS taken at the beginning of treatment was 1.65 (0-5); at the $3^{\text {rd }}$ month the mean score was $9(8-10)$ and it remained similar at the $12^{\text {th }}$ month $-8.67(7-10)$.

Conclusions: Theresienöl herbal oil treatment of vulvar leukoplakia is effective and safe, but studies should be continued.
\end{abstract}

Key words: vulvar leukoplakia, vulvar lichen sclerosus, vulvar squamous cell hyperplasia, treatment, Theresienöl.

\section{Introduction}

The term vulvar leukoplakia encompasses various non-inflammatory diseases that lead to skin discoloration of the external genitalia and white coloration. It includes various atrophic and hypertrophic diseases of the vulva, classified as vulvar dystrophies [1]. Mainly, these are vulvar lichen sclerosus (VLS) and squamous cell hyperplasia of the vulva (SCHV). These 2 conditions have different anatomical and pathological features but similar clinical manifestations and drug treatment. The frequency is 1 in 300-1000 [2].

Both diseases are easily clinically diagnosed, which is sufficient for clinical practice. However, their exact differentiation is histologically made after biopsy $[3,4]$. Genital itching is the main clinical manifestation of both diseases and is more pronounced in SCHV [5]. Topical corticosteroids are the gold standard for their treatment $[6,7]$. They present a very good result but have some side effects as well, such as atrophy, telangiectasia, and striae, and long-term use is not recom- mended. In addition, some cases are resistant to this therapy. For these reasons, other methods of VLS and SCHV treatment should be sought and used in practice.

We present 15 patients clinically diagnosed with VLS and SCHV, who were treated with Theresienöl herbal oil and monitored for 1 year.

\section{Material and methods}

This prospective study included 17 patients (15 of whom were in menopausal status) who were treated at a consulting-diagnostic centre at the Department of Gynecologic Oncology, D-r Georgi Stranski University Hospital - Pleven, for a period of 8 months (Jan. $1^{\text {st }}, 2018$ - Aug. 31 $\left.1^{\text {st }}, 2018\right)$. All of them were clinically diagnosed with vulvar leukoplakia (VLS and SCHV). The prescribed treatment was topical administration of Theresienöl twice a day for 3 months.

One of the essential ingredients of this ointment is Butyrum bovis, which is a carrier of all active ingredi- 
ents of Theresienöl - tocopherol and tocopherol acetate. They have effect on the repair of cells and on the epithelisation of the injured skin. This protects against scar and blister formation. The other ingredient is a fruit extract from Pyrus malus, which is rich in polyphenols - this is the reason for the antioxidant effect of the ointment. Theresienöl contains tannic and salicylic acids, which are responsible for the skin $\mathrm{pH}$. The product contained the leaf extract from Stellarioides longibracteata, which has anti-fungal and antibacterial effects. It improves blood circulation and oxygenation and plays an important role in wound healing. The saponins contained in the ointment have anti-inflammatory, coagulation, and hormone stimulating effects and help treat swelling and haematomas

The 1-year follow-up reported the results obtained from visual analogue scale (VAS) assessment for vulvar itching (Fig. 1). Follow-up visits were at the beginning and at the end of the Theresienöl treatment, and 1 year after its initiation.

\section{Results}

The median age of the patients enrolled was 60.6 years (range 42-74). Seven of these cases were patients with recurrent disease (treated for vulvar leukoplakia at least 1 year ago); 5 of them were classified as VLS and 2 as SCHV. In 4 of the cases we had a previous histological examination -1 case with SCHV and 3 with VLS. Two of the patients failed to attend the follow-up visits after the end of treatment. For this reason, they were omitted

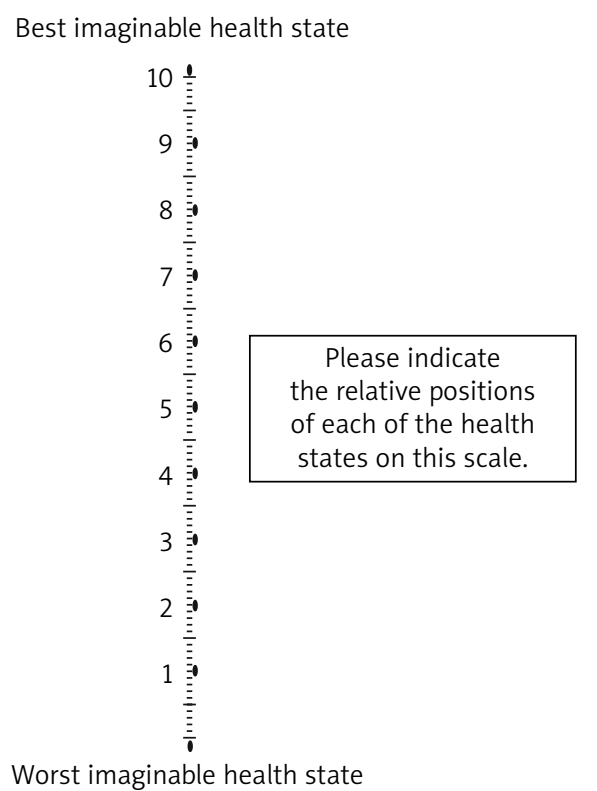

Fig. 1. Visual analogue scale

from the study. Some of the clinical and pathological characteristics of the patients are presented in Table 1.

It is noteworthy that all patients considered vulvar itching as a very serious problem. The average score that we reported initially using VAS was 1.65 (0-5). There was a significant improvement in itching in all patients, as early as the $10^{\text {th }}$ day of treatment, with a median score of 9 (8-10) at the $3^{\text {rd }}$ month. The score remained at almost the same level at the $12^{\text {th }}$ month - 8.67 (7-10). No side effects and recurrence of symp-

Table 1. Clinical and pathoanatomical characteristics of patients

\begin{tabular}{|c|c|c|c|c|c|c|c|}
\hline & Age & $\begin{array}{l}\text { Clinical } \\
\text { diagnosis }\end{array}$ & Disease & $\begin{array}{c}\text { Previous histological } \\
\text { examination }\end{array}$ & $\begin{array}{l}\text { VAS assessment } \\
\text { - starting levels }\end{array}$ & $\begin{array}{l}\text { VAS assessment } \\
-3^{\text {rd }} \text { month }\end{array}$ & $\begin{array}{l}\text { VAS assessment } \\
-12^{\text {th }} \text { month }\end{array}$ \\
\hline 1 & 55 & SCHV & New & $\mathrm{n} / \mathrm{a}$ & 1 & 9 & 8 \\
\hline 2 & 59 & VLS & New & $\mathrm{n} / \mathrm{a}$ & 1 & 9 & 8 \\
\hline 3 & 67 & VLS & Relapse & VLS & 1 & 8 & 9 \\
\hline 4 & 42 & VLS & New & $\mathrm{n} / \mathrm{a}$ & 5 & 10 & 10 \\
\hline 5 & 69 & VLS & Relapse & VLS & 1 & 9 & 7 \\
\hline 6 & 71 & $\mathrm{SCHV}$ & New & $\mathrm{n} / \mathrm{a}$ & 3 & 10 & 10 \\
\hline 7 & 50 & VLS & New & $\mathrm{n} / \mathrm{a}$ & 0 & 8 & $\mathrm{n} / \mathrm{a}$ \\
\hline 8 & 55 & VLS & Relapse & $\mathrm{n} / \mathrm{a}$ & 2 & 8 & 9 \\
\hline 9 & 62 & VLS & New & $\mathrm{n} / \mathrm{a}$ & 2 & 8 & 7 \\
\hline 10 & 66 & $\mathrm{SCHV}$ & Relapse & $\mathrm{SCHV}$ & 1 & 9 & $\mathrm{n} / \mathrm{a}$ \\
\hline 11 & 48 & VLS & New & $\mathrm{n} / \mathrm{a}$ & 4 & 10 & 9 \\
\hline 12 & 60 & VLS & Relapse & $\mathrm{n} / \mathrm{a}$ & 2 & 10 & 10 \\
\hline 13 & 55 & $\mathrm{SCHV}$ & New & $\mathrm{n} / \mathrm{a}$ & 3 & 9 & 10 \\
\hline 14 & 63 & VLS & New & $\mathrm{n} / \mathrm{a}$ & 1 & 9 & 8 \\
\hline 15 & 74 & VLS & Relapse & VLS & 0 & 8 & 9 \\
\hline 16 & 70 & VLS & New & $\mathrm{n} / \mathrm{a}$ & 0 & 10 & 8 \\
\hline 17 & 65 & $\mathrm{SCHV}$ & Relapse & $\mathrm{n} / \mathrm{a}$ & 2 & 9 & 8 \\
\hline
\end{tabular}

VAS - visual analogue scale, SCHV - squamous cell hyperplasia of the vulva, VLS - vulvar lichen sclerosus, n/a - not applicable 
toms after the end of treatment were observed during the follow-up period.

\section{Discussion}

The occurrence of VLS and SCHV is determined by many factors such as immunity, sexual hormones, injuries, environment, enzymes, free radicals, and apoptosis. It is assumed that VLS and SCHV are genetic immune diseases [5]. Both are diseases of autoimmune genesis, with genetic predisposition for VLS [1, 5, 8]. Both diseases are more common in postmenopausal women [1, 9-11]; with VLS there is also a peak in pre-pubertal girls [12-14]. In VLS the vulva is shiny, dry, with no creases. Lesions are often symmetrical, and the skin appears thin. With $\mathrm{SCHV}$, the skin is rough and thick. Thickened plaquelike lesions containing maturing squamous proliferation with hyperkeratosis and/or parakeratosis is observed.

The clinical picture in both diseases is similar - pruritus, pain when having sex, dysuria, or dyspareunia with itching being the leading symptom. Both conditions have malignant potential -3 to $6 \%$ for VLS and 2 to $4 \%$ for SCHV [5]. Long-term follow-up for these patients is required.

Treatment with topical corticosteroids in different doses and duration is the first-line therapy for these conditions. Topical corticosteroids relieve the symptoms in almost $100 \%$ of cases. In about $70 \%$ of cases, symptoms disappear completely, and in $20 \%$ - complete recovery of the skin is observed [7]. The side effects of these drugs are known; however, it should be noted that they are not well documented when administered to the vulva skin [15]. Nevertheless, their use should be limited to achieving the necessary effect.

In patients refractory to this treatment, alternative methods in different operating modes are used: topical hormonal products [16], topical and systemic retinoids [17], topical calcineurin inhibitors [18], Platelet-rich plasma [19], ablative lasers (carbon dioxide laser) [20-23], and non-ablative neodymium: yttrium aluminium garnet (Nd: YAG) [24]. Surgical treatment of both diseases should be avoided because of recurrence risk and should only be used in certain cases, such as patients with malignancy, or to correct irreversible scarring, adhesions, and micturition difficulties or sexual dysfunction caused by the subsequent anatomical changes [7].

We decided to use Theresienöl herbal oil for topical treatment due to its mechanism of action: it hydrates the tissues, reduces bacterial invasion and inflammation, stimulates fibroblast and endothelial cell migration and proliferation, and stimulates epithelialisation. Thereby, it has an analgesic, antiseptic, moisturising, and itchy skin reducing effect. The other reason for our decision was our previous experience with this product - we used it for the treatment of postpartum perineal tears, chronic wounds, ulcus cruris, postoper- ative wounds, perianal fissures, burns grade 2 a and $2 \mathrm{~b}$, etc. [25]. The results obtained are promising. However, this study bears some weaknesses: a small number of patients, a relatively short follow-up period, a lack of control group, and a lack of histological verification. Our previous experience with topical steroids leads us to believe that the Theresienöl effect is commensurable with them, as with response time and duration of action. Furthermore, there were no adverse events reported.

\section{Conclusions}

Vulvar leukoplakia comprises a set of diseases impairing patients' quality of life. Standard forms of treatment - conservative and operative - have their limitations, side effects, and complications. This calls for alternative methods to influence them, such as the use of Theresienöl, which is a safe and effective option. Monitoring of these patients should continue, especially given the malignant potential of the disease.

\section{Disclosure}

The authors report no conflict of interest.

\section{References}

1. Tsikouras P, Anthoulaki X, Deftereou T, et al. Depigmentation's disorders of the vulva, clinical management. In: Kim T-H (ed.). Depigmentation. IntechOpen 2019.

2. Viana Fde O, Cavaleiro LH, Unger DA, Miranda MF, Brito AC. Acral lichen sclerosus et atrophicus - case report. An Bras Dermatol 2011; 86: 82-84.

3. Halonen P, Jakobsson M, Heikinheimo O, Riska A, Gissler M, Pukkala E. Lichen sclerosus and risk of cancer. Int J Cancer 2017; 140: 1998-2002.

4. Chan MP, Zimarowski MJ. Vulvar dermatoses: a histopathologic review and classification of 183 cases. J Cutan Pathol 2015; 42: 510-518.

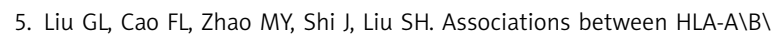
DRB1 polymorphisms and risks of vulvar lichen sclerosus or squamous cell hyperplasia of the vulva. Genet Mol Res 2015; 14: 15962-15971.

6. Ayhan A, Guvendag Guven ES, Guven S, Sakinci M, Kucukali T. Medical treatment of vulvar squamous cell hyperplasia. Int J Gynaecol Obstet 2006; 95: 278-283.

7. Fistarol SK, Itin PH. Diagnosis and treatment of lichen sclerosus: an update. Am J Clin Dermatol 2013; 14: 27-47.

8. Berth-Jones J, Graham-Brown RAC, Burns DA. Lichen sclerosus. Arch Dis Child 1989; 64: 1204-1206.

9. Soper JT, Creasman WT. Vulvar dystrophies. Clin Obstet 1986; 29: 431-439.

10. Kaufman RH, Gardner HL, Brown Jr D, Beyth Y. Vulvar dystrophies: an evaluation. Am J Obstet Gynecol 1974; 120: 363-367.

11. Barbero M, Micheletti L, Borgno G, Cavanna L, Preti M, Ghiringhello B. Vulvar dystrophies in young and premenopausal women. J Reprod Med 1988; 33: 555-558.

12. Cooper SM, Gao XH, Powell JJ, Wojnarowska F. Does treatment of vulvar lichen sclerosus influence its prognosis? Arch Dermtol 2004; 140: 702-706.

13. Wallace HJ. Lichen sclerosus et atrophicus. Trans St Johns Hosp Dermatol Soc 1971; 57: 9-30.

14. Powell J, Wojnarowska F. Childhood vulvar lichen sclerosus: an increasingly common problem. J Am Acad Dermatol 2001; 44: 803-806.

15. Neill SM, Lewis FM, Tatnall FM, Cox NH. British Association of Dermatologists' guidelines for the management of lichen sclerosus 2010. $\mathrm{Br}$ J Dermatol 2010; 163: 672-682. 
16. Rioux JE, Devlin C, Gelfand MM, Steinberg WM, Hepburn DS. 17-beta-estradiol vaginal tablet versus conjugated equine estrogen vaginal cream to relieve menopausal atrophic vaginitis. Menopause 2000; 7: 156-161.

17. Khalil S, Bardawil T, Stephan C, et al. Retinoids: a journey from the mo lecular structures and mechanisms of action to clinical uses in dermatology and adverse effects. J Dermatolog Treat 2017; 28: 684-696.

18. Kim GW, Park HJ, Kim HS, et al. Topical tacrolimus ointment for the treatment of lichen sclerosus, comparing genital and extragenital involvement. J Dermatol 2012; 39: 145-150.

19. Kim SH, Park ES, Kim TH. Rejuvenation Using platelet-rich plasma and lipofilling for vaginal atrophy and lichen sclerosus. J Menopausal Med 2017; 23: 63-68.

20. Lee A, Lim A, Fischer G. Fractional carbon dioxide laser in recalcitrant vulval lichen sclerosus. Australas J Dermatol 2016; 57: 39-43.

21. Origoni M. Fractional carbon dioxide laser in recalcitrant vulvar lichen sclerosus. Australas J Dermatol 2017; 58: e157-158.

22. Stuart GC, Nation JG, Malliah VS, Robertson DI. Laser therapy of vulvar lichen sclerosus et atrophicus. Can J Surg 1991; 34: 469-470.

23. Volz J, Blanke M, Melchert F. [Treatment of therapy refractory squamous epithelial hyperplasia of the vulva by $\mathrm{CO} 2$ laser vaporization]. Geburtshilfe Frauenheilkd 1994; 54: 406-408.

24. Bizjak Ogrinc U, Senčar S, Luzar B, Lukanović A. Efficacy of non-ablative laser therapy for lichen sclerosus: a randomized controlled trial. J Obstet Gynaecol Can 2019; 41: 1717-1725.

25. Strashilov S, Slavchev S, Aljowder A, et al. Austrian natural ointment (Theresienöl $\left({ }^{\circledR}\right.$ ) with a high potential in wound healing - a European review. Wound Med 2020; 30: 100191. 